\title{
VISION OF COMMUNICATORS REGARDING TO THE FUTURE OF BROADCASTING AND NEW MEDIA.
}

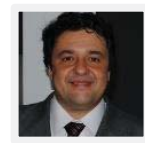

Moderator: Fernando Moura

Dr.Prof of Social Communication - Univ. Anhembi Morumbi (UAM) / Senior Editor, SET magazine.

Introduction to the vision of communication in a converging world

Speaker: Francisco Machado Filho

Professor of Journalism / UNESP Bauru

The future of radio at convergence context and the migration from AM to FM

Speaker: Nivaldo Ferraz

Dr. Professor and Coordinator - Journalism Course at the School of Communication / Anhembi-Morumbi University / Specialist in radio

Streaming, mobilidade e TV em toda parte

Speaker: Renato Cruz

Editor / inova.jor 


\section{VISION OF COMMUNICATORS REGARDING TO THE FUTURE OF BROADCASTING AND NEW MEDIA}

Moderator: FERNANDO MOURA - Dr.Prof of Social Communication - Univ. Anhembi Morumbi (UAM) / Senior Editor, SET magazine.

In this session, Brazilian communication academic will have the opportunity to analyze the changes in the audiovisual production chain, focusing on content distribution and how audience behavior is changing in the light of new demands in television engineering in Terrestrial Digital TV, and on the new platforms for audiovisual distribution using streaming, whether VoD or OTT. This is a unique opportunity to exchange experiences with those that provide the support and the tools for producing and distributing content.

- Introduction to the vision of communication in a converging world Speaker: Francisco Machado Filho Professor of Journalism / UNESP Bauru

Technological convergence has been changing how audiences consume television products. In the United States, the strategy used for dealing with this new context is localism. And in Brazil? Would this strategy work? This is the premise behind the research done in Austin, Texas by Professor Francisco Machado Filho, which compares local television reality in that city and indicates parallels in the reality of local communication in both countries

- The future of radio at convergence context and the migration from AM to FM Speaker: Nivaldo Ferraz

Dr. Professor and Coordinator - Journalism Course at the School of Communication / AnhembiMorumbi University / Specialist in radio

O que se perde em termos sociais com a migração do AM para o FM, no contexto de um país com significativa população rural, índice de analfabetismo e exclusão digital. A restrição definitiva do broadcasting e do grande público radiofônico. O favorecimento de um modelo de programação de rádio local para uma onda em FM, que viaja em amplitude menor no espaço. Uma discussão sobre o quanto a qualidade de programação melhora em proporção à melhora do sinal sonoro na comparação do AM para o FM.

- Streaming, mobilidade e TV em toda parte Speaker: Renato Cruz Editor / inova.jor

O avanço da banda larga torna o vídeo cada vez mais importante nos serviços online. Mas até que ponto o vídeo que se faz hoje para ser compartilhado em redes sociais pode ser chamado de televisão? O Streaming deixou de lado o conceito de grade de programação, e tecnologias como virtualização e computação em nuvem tornam obsoleta a ideia de televisão como uma operação local. O futuro da TV é um aplicativo? 


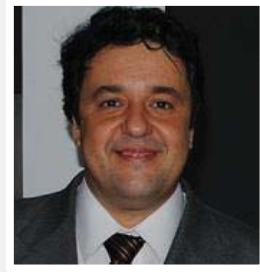

\section{FERNANDO MOURA}

Senior Editor - SET Magazine

Dr. Fernando Carlos Moura is a Professor and Researcher at the Media and Journalism Investigation Center (CIMJ), School of Social Sciences and Humanities, New University of Lisbon (UNL) and, since 2013, senior editor of the SET magazine.

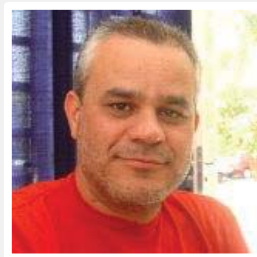

\section{FRANCISCO MACHADO FILHO}

Professor of Journalism / UNESP Bauru

15 years' experience in producing and directing TV programs. Holds a Doctorate in Digital TV from UMESP-SP. Specialist in Communication Advisory Management. University professor on social communication courses

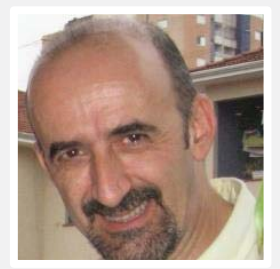

Specializations: Communication Advisory Management, Digital TV, Internet and Digital Marketing

\section{NIVALDO FERRAZ}

Dr. Professor and Coordinator - Journalism Course at the School of Communication / AnhembiMorumbi University / Specialist in radio

Earned a Doctorate from the Graduate Program in Audiovisual Means and Processes of the ECAUSP. Holds a Master's from ECA-USP. Holds a degree in Journalism from the Methodist University of São Paulo. Professor of Radio Reporting and Documentaries, Sound Language and an Experimental Project in Journalism. Editor of articles by students of the Anhembi-Morumbi University for the University on the Air segment of CBN Radio - São Paulo. Reporter, program director, presenter, copywriter and editor at the Cultura AM and FM Radio stations in São Paulo, USP FM Radio and Gazeta AM and FM Radio in São Paulo (1990's and the year 2000).

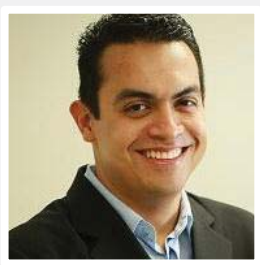

Copywriter and character in comedy, drama and suspense programs in radio projects for USP- FM Radio and advertising company, Lintas Publicidade (1980's).

\section{Renato Cruz}

\section{Editor - inova.jor}

He is editor of inova.jor, a site for news about technology and innovation, and a professor at the Senac University Center. He was a reporter and columnist for the O Estado de S. Paulo newspaper. He has published the books $\mathrm{O}$ desafio da inovação: a revolução do conhecimento nas empresas brasileiras (published by Senac São Paulo); TV digital no Brasil: tecnologia versus política (published by Senac São Paulo) and O que as empresas podem fazer pela inclusão digital (Ethos/CDI). He holds an undergraduate degree in journalism, as well as a Master's and a Doctorate in Communication Sciences from the University of São Paulo. 